\title{
Adaptation opportunities for water security in Brazil
}

\author{
Oportunidades de adaptação para a \\ segurança hídrica no Brasil
}

Vânia Rosa Pereira ${ }^{a}$

Daniel Andrés Rodriguez ${ }^{\mathrm{b}}$

Sonia Maria Viggiani Coutinhoc

Diogo Victor Santos ${ }^{d}$

José Antônio Marengo ${ }^{\mathrm{e}}$

a PhD in Geography, State University of Campinas, Campinas, SP, Brazil

E-mail: rosa.vania@gmail.com

${ }^{b}$ PhD in Meteorology, Federal University of Rio de Janeiro, Rio de Janeiro, RJ, Brazil

E-mail: daniel.andres@coc.ufrj.br

c PhD in Sciences, University of São Paulo, São Paulo, SP, Brazil

E-mail: scoutinho@usp.br

${ }^{d}$ Ministry os Science, Technology and Innovations (MCTI). Brasília, DF, Brazil E-mail:diogo.santos@mctic.gov.br

e Center for Monitoring and Early Warnings of Natural Disasters - Cemaden,

São José dos Campos, SP, Brazil

E-mail: jose.marengo@cemaden.gov.br

doi:10.18472/SustDeb.v11n3.2020.33858

Data and results presented in this article were developed under the project of the "Fourth National Communication and Biennial Update Reports of Brazil to the Climate Convention", coordinated by the Ministry of Science, Technology and Innovations, with the support of the United Nations Development Programme and resources of the Global Environment Facility, to which we offer our thanks.

\section{ABSTRACT}

We sought to identify priorities and adaptation opportunities for water security across the various Brazilian biomes. With ever-growing demand and water-usage, future climate scenarios suggest that further water resources management constraints are to be endured throughout the next two decades. 
The unbalance between high-quality water demand and availability in a multisectoral usage context (e.g., domestic, industry, agribusiness) highlights the socio-ecological Nexus+ concept's relevance. In this context, the political and cross-institutional articulation and flexibility play a significant role in steering adaptative actions. These challenges in defining action plans, adequately addressed at a multiscale level with inherent climatic uncertainties, are yet to be overcome in Brazilian water resources management.

Keywords: Water security. Climate change. Nexus+. Adaptation opportunities. Brazilian biomes.

\section{RESUMO}

Neste trabalho buscamos identificar as questões prioritárias e as oportunidades de adaptação para a segurança hídrica nos diferentes biomas brasileiros. A redução da disponibilidade hídrica prevista em cenários de clima futuro, as projeções crescentes de retirada para os próximos 20 anos e os conflitos de uso múltiplo da água atuais, indicam um cenário de amplificação dos desafios já existentes no futuro próximo. Os desbalanços entre demanda e disponibilidade de água com qualidade num contexto multisetorial evidenciam a abordagem nexus+água-alimento-energia-socioambiental. Neste contexto, a articulação e flexibilidade político-institucional destacam-se como questões centrais para direcionar ações de adaptação. A articulação entre diferentes instituições e políticas públicas em abordagem multiescalas (municipal, de bacias hidrográficas, estadual e federal), assim como a consideração da incerteza climática nas ações de planejamento, ainda são desafios a serem superados na gestão dos recursos hídricos.

Palavras-chave: Segurança hídrica. Mudanças climáticas. Nexust. Oportunidades de adaptação. Biomas brasileiros.

\section{INTRODUCTION}

Water is a minimum requirement for life and capital goods, so its scarcity or excess can become a source of destruction, poverty, and conflict. Water security understanding goes beyond water deficit assessments since the problems associated with water resources are highly intricate (BOELENS et al., 2014). It evolves economic, social, health, and environmental aspects. Given the multidimensional water security character, its approach requires a transdisciplinary view through the socio-ecological system (LIEHR et al., 2017).

The literature presents a wide range of concepts for water security, depending on the purpose, focus, and scale of analysis (COOK \& BAKKER, 2012). The common point of these concepts is meeting the basic needs for human survival and ensuring water quantity and quality. Attentive to the processes of global environmental change, holistic views adopt concepts that integrate human needs with environmental protection, i.e., ecosystems, public health, and disaster risk management that has water as a vector (UN WATER, 2013; WATERAID, 2012; WWC, 2013, OECD, 2013, VAN BEEK \& ARRIENS, 2014).

In this work, the water security is conceptualized as the availability of an acceptable quantity and quality of water for health, livelihoods, ecosystems, and production coupled with an acceptable level of water-related risks to people, environments, and economies (GRAY \& SADOFF, 2007).

The nexus concept addresses the interdependencies between water-energy-food subjects, emerging as a response to anthropogenic climate change (AGRAWAL \& LEMOS, 2015; ENDO et al., 2017; FROESE \& SCHILLING, 2019; HOFF, 2011). The nexus + approach, adopted in this work, adds socio-environmental issues to the water-food-energy relationship, considering that socio-environmental inequalities increase the vulnerability and exposure of societies (MILHORANCE AND BURSZTYN (2019); ARAÚJO et al. (2019); BOELENS et al., 2014; COUTINHO et al., 2020). Adaptation actions are the adjustments that society needs to make in facing the climate change effects. 
The directions for adaptation policies to explore opportunities and minimize the risks and impacts of climate change depends on the society's vulnerability and exposure levels. Also, consider and identify synergies and trade-offs between adaptation options (LEMOS et al., 2016) helps to guide the actions. Water, food, energy, and socio-environmental security are related to the availability, access, and fair distribution of these resources. Environmental protection and economic development involve political, circumstances, and institutional issues (SIMPSON \& JEWITT, 2019).

In this perspective, to achieve water security, it is necessary to build adaptation capacity (LEMOS et al., 2016) and balance human needs for consumption and development. At the same time, ensure the maintenance of biodiversity and ecosystem services.

This paper seeks to identify and prioritize water security adaptation issues and opportunities in different Brazilian biomes according to the nexus + approach.

\section{VULNERABILITY AND IMPACTS OF CLIMATE CHANGE FOR WATER SECURITY}

\subsection{THE RELEVANCE OF WATER SECURITY IN BRAZIL}

The hydrographic basin climate and hydrological regime steer the economy and the Brazilian population's lifestyles. Economic activities, such as agriculture, industry, and electricity production, are dependent on the climate, water availability, and water quality in the region where they are developed (PBMC, 2014).The high population density combined with the water resources demands and the pollution challenges can generate conflicts of use due to their quality and quantity unbalance. Among the 73 Metropolitan Regions and the 07 Integrated Development Regions (RIDEs) in Brazil, 28 have more than 1 million inhabitants and add up to a total of 98.7 million inhabitants, representing $47.3 \%$ of the Brazilian population (IBGE, 2018). São Paulo and Rio de Janeiro alone - the two largest Brazilian megacities - have more than 18 million people. Only $63.5 \%$ of the Brazilian population uses sewage services managed safely, including facilities for washing hands with soap and water (ANA, 2019).

Water use demand in Brazil is steadily growing, with an increase of approximately $80 \%$ in the total withdrawn in the last two decades. Withdrawals for multiple water users, including economic activities, may increase by 24\% in Brazil, in 2030, compared to 2017 (ANA, 2018).

Crop irrigation accounts for $52 \%$ of the withdrawal flow and $68.4 \%$ of the consumed flow, which places it as the highest used activity (ANA, 2018). Taking the 2015 estimates as a starting point, incorporating 3.14 million hectares of irrigated crops is projected, bringing the country closer to the total area of 10.09 million hectares irrigated in 2030 (ANA, 2017).

There is also a demand for electricity production since Brazil is one of the world's largest hydraulic electricity producers. In 2018 , the country registered $66.6 \%$ of the domestic electricity supply based on hydraulic sources (MME, 2019).

The Brazilian regions have heterogeneous climatic and socio-environmental water resource contexts. Some regions have historically lived with droughts, such as the Brazilian semi-arid region. In contrast, others have demand that exceeds water systems' capacity due to population pressure, such as the Southeast.

Ecosystem services such as fish farming, water supply, and recreation are connected to the hydrological cycle in the basin-scale for water purification, retention, and climate regulation. Sustainable water resources management and use are linked to ecosystem services (GRIZZETTI et al., 2016) since aquatic ecosystems enable vast biodiversity and are sources of inspiration, income, nutrition, and food 
security. Ecosystems services represent a Brazilian cultural heritage, therefore being part of the critical components to consider in the natural resource management and conservation actions (BPBES, 2020).

The anthropic pressure in the Caatinga, Cerrado, Atlantic Forest, and Amazon biomes alter the ecosystem's balance, affecting their services (JOLY et al., 2019). The ecosystem's alterations can lead to situations of a tipping point, i.e., in which it can no longer regenerate (NOBRE et al., 2016; SAMPAIO et al., 2019).

\subsection{WATER SECURITY AND CLIMATE CHANGE: IMPACT CHAIN}

Climate change results in physical process alterations that, in turn, trigger socio-environmental impacts, putting at risk the well-being and population lifestyle that organizes itself in order to adapt public policies (Figure 1).

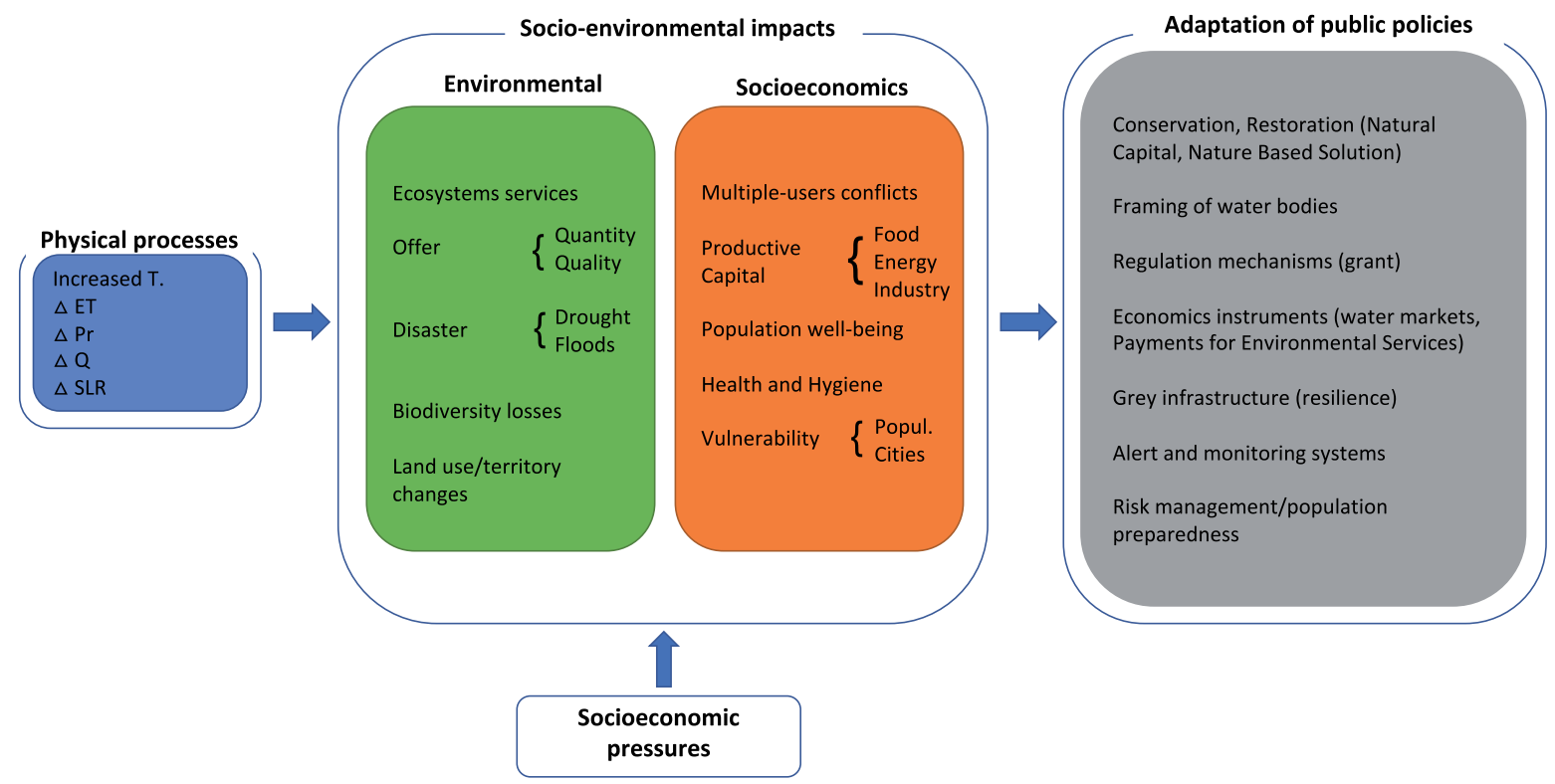

Figure 1 | Impact chain of water security and adaptive responses in public policies related to climate change.

Delta (D) represents the physical processes variation resulting from climate change, i.e., alterations in evapotranspiration (ET), precipitation (Pr), flow rate (Q), and sea level rise (SLR).

Source: Prepared by the authors.

The variability, seasonality, and intensification of the physical process -i. e., precipitation pattern, potential evapotranspiration, river flow, biogeochemistry of water bodies and oceans, and sea level rise - are the most preeminent climate change effects on the hydrological cycles (MAGRIN et al., 2014). Environmental impacts result in changes in the water supply and its quality, the frequency and magnitude of extreme events, soil loss, the alteration/destruction of its territories, and biodiversity. These environmental impacts affect the general well-being, health, and hygiene conditions and interfere in productive capacity and exacerbate conflicts over water resources, triggering and deepening water crises. Consequently, current public policies may prove insufficient or even inadequate to deal with current and future challenges. Thus, they should be prone and flexible to adapt and mitigate the new reality's side effects.

\subsection{CLIMATIC IMPACTS OBSERVED IN BRAZIL}

The drought or dry season events caused Emergency Situation or Public Calamity State declarations at least once in 51\% of Brazilian municipalities between 2003 and 2015. Also, 48\% of the municipalities 
declared an emergency or public calamity due to floods at least once between 2003 and 2017 (ANA, 2018). The Northeast, South, and Southeast regions placed about $89 \%$ of these municipalities that suffered from flood events. However, prominent events have occurred in other regions, such as the North.

The Northeast's semi-arid region has experienced the sequence of most extended and intense droughts in recent decades since 2010 (MARENGO et al., 2017; MARENGO, ALVES, et al., 2018). Brito et al. (2018) identified that all states in northeastern Brazil's semi-arid region, in a 36-year interval between 1981 and 2016, were affected by droughts in approximately more than half of the analyzed interval. Brito et al. (2018) also highlight the occurrence of more frequent, prolonged, and severe droughts in the most recent period, between 2011 and 2016.

The municipalities of Caatinga and Cerrado recorded the highest numbers of droughts between 2003 and 2015. About $80 \%$ of the people affected by droughts in 2017 live in the Northeast Region. Bahia, Ceará, and Pernambuco accounted for $55 \%$ of people affected in the country. The water rationing in 2017 recorded the highest average number of people affected by events in the federal capital's water crisis (ANA, 2018).

In April 2018, the criticality in urban supply decreased. However, water sources' depletion still collapsed 34 cities in Bahia, Ceará, and Paraíba (ANA, 2018).

The combination of longer dry seasons and delayed onset of rains increased the risk of extreme droughts and forest fires in the Amazon region. Episodes of drought in the years 2005, 2010, and 2016 have influenced the frequency of forest fires and carbon balances (ARAGÃO et al., 2018; MARENGO, SOUZA, et al., 2018), with high mortality rates of trees (BRIENEN et al., 2015).

In the Cerrado, the low precipitation rates at the end of 2016 impacted the Federal District's main supply reservoirs' storage. A 70\% drop in agricultural production and a 30\% drop in the planted area increased up to $100 \%$ in food goods were registered.

In the Tocantins River basin, since 2012, the volume stored in the reservoirs has been decreasing. In 2017, the Serra da Mesa reservoir reached just under $6 \%$ of its useful volume, registering the lowest observed value.

The prolonged drought in the Southeast in 2014 caused vast impacts that affected several sectors. The industry's production capacity, crop yields, hospitals, and schools' operation were compromised (NOBRE et al., 2016). Agricultural products and commodities, such as sugar cane, coffee, beans, and oranges, registered production losses. The sugarcane harvest, for example, had a $5 \%$ reduction.

The rain shortage in 2014 and 2015 in the Southeast Region also affected activities on the most critical waterways in the country, in terms of values and volumes transported (ANA, 2019). The lack of demolition works and reduced defluent flow rate paralyzed the Ilha Solteira and Três Irmãos waterways from 2014 to 2016.

The floods affected 2716 Brazilian municipalities between 2003 and 2018 (ANA, 2019). The highest frequencies of flood events were recorded mainly in the Northeast, South, and Southeast regions. The floods affected about 1 million people in Brazil in 2018. The most noticeable human damage due to the floods is the loss of the affected persons' homes. More severe damages (deaths, disappearances, illnesses, and injuries) affected less than $5 \%$ of these people.

In the South of Brazil, a sequence of extreme precipitation events caused severe floods and landslides in 2008 in the Itajaí River Valley. The event affected around 1.5 million people from Santa Catarina, with 135 dead and 80,000 displaced. The low-income populations were the most affected, showing the relationship between the disaster impacts and the regional development condition (AVILA \& MATTEDI, 2017). 
In 2014, a historic flood on the Madeira River isolated the state of Acre from Brazil for about 30 days. The floods hit the main highway and caused shortages in the cities, loss of production of the riverside population, and increased diseases transmitted by water contamination such as leptospirosis (FRANCA \& MENDONÇA, 2015).

\subsection{CONDITIONING FACTORS FOR WATER SECURITY IN BRAZILIAN BIOMES}

The current environmental and socioeconomic status for each Brazilian biome constitutes conditioning factors for their climate change impacts and vulnerability. The populous cities, limited sanitation services and access to water in quantity and quality, and anthropic pressures on ecosystems related to urban and agricultural expansion are potential barriers to achieving water security.

The Brazilian Amazon biome is deficient in infrastructure and sanitation services. Besides, the legal water resources management instruments, such as state plans (PERHs) and river basin committees (CBHs), are still in the initial development stage, when they are not wholly absent. According to ANA (2019), concerning PERHs, Amazonas, and Pará, they are still being contracted, and Amapá does not yet have them. The state of Amazonas has $2 \mathrm{CBHs}$, while Amapá, Rondônia and Acre have none. This biome also stands out for its incipient water quality monitoring gauges. These deficiencies reveal a critical situation of weak regional governance to deal with and know the impacts of extreme drought and flood events. The region may become even more vulnerable in the face of climate change considering socioeconomic pressures such as the current deficit in infrastructure, sanitation, monitoring gauges, deforestation, poverty, and traditional people lifestyle.

The Free Economic Zone of Manaus is an industrial hub responsible for $1.4 \%$ of the national GDP and makes intense use of the Alter do Chão Aquifer system (AAC). A reduction in its water level due to a scenario of overexploitation was identified, considering the economic and environmental aspects (SARAIVA, 2017).

In the Cerrado, the relationship between supply and demand is currently alarming, as it has intensive water withdrawals from ground and surface for crop irrigation. The Midwest placed the largest expansion of irrigated areas in the country between 1996 and 2015 and quadrupled its irrigated area to 1.2 million hectares (ANA, 2017). The limited accessibility to sewage services, especially rural sanitation, the nonpoint source pollution, and groundwater contamination, is considered the current context's vulnerabilities (ANA, 2019). Climate change can amplify the current risks of growing demand and losses in biodiversity.

The pressures caused by the population increase in the Guarani Aquifer indicate a probable increase in exploration in the long term, which can cause the decrease of its water level and, consequently, influence the operational conditions of the existing wells, causing conflicts (BOICO \& WENDLAND, 2018).

The Caatinga presents the worst situation in terms of water resources availability in the current context. Water exploration is critical and requires intense management activity and large investments in infrastructure. This situation is due to its natural water deficit and anthropic pressure with intense withdrawals from the big urban centers and the irrigated agriculture hubs. Because the socioeconomic pressures such as the current deficit in infrastructure and sanitation, associated with poverty, and the significant dependence on family farming, the region may become even more vulnerable in quality and water quantity (MARENGO et al., 2020).

The Atlantic Forest has satisfactory water security conditions compared to other biomes. However, in its large metropolitan centers, water exploration is considered critical, requiring intense management activity and large investments. The integrated water supply systems, which serve several municipalities and development hubs interconnected and simultaneously adds complexity to planning in this biome. 
The conditions to water quality and security in the face of extreme flood events are still limited and well below world averages. Socioeconomic pressures, such as social inequality; deficient infrastructure, especially urban drainage; irregular occupations; high production and consumption; and agricultural activities, place the biome in a vulnerable situation in climate change scenarios (SCARANO \& CEOTTO, 2015). These pressures can increase episodes of floods and landslides and waterborne diseases, as well as crop losses.

In the Pantanal, although its currently high water availability, there are deficits in infrastructure, sanitation services, and water quality monitoring and control that impose an alert situation for water security (TOMAS et al., 2019). The legal instruments for water resources management, such as state plans and river basin committees, are still in an initial development stage and reveals a situation of fragility in regional governance.

Pampa biome has high water availability in the current climate context, accessibility to sanitation services above the average of other biomes, and water resource management instruments in action. However, socioeconomic pressures, such as increasing demand for agricultural production, especially the irrigated rice crops, lack of clear policy for nonpoint pollution control, and groundwater contamination potential, are the flaws under climate change. Extreme drought and flood events show that impacts related to floods and water quality changes, such as conflicts over multiple water use and biodiversity losses, can be amplified (RIBEIRO NETO et al.,2016; BPBES, 2020).

The Brazilian coastline is susceptible to sea level rises and more intense hangovers. This portion of the territory has been affected by increased erosion and coastal flooding. Asset losses, services restrictions, reduced livable spaces, marine intrusion, and biodiversity and fishery production losses are examples of the associated impacts. The water quality changes due to saturation and salinization that flow into the coast are at risk (PBMC, 2017).

The Atlantic Forest, Cerrado, and Amazon biomes place the vulnerable Protected Areas (PA) in size, native vegetation cover, and climate-driven vegetation transition (Lapola et al., 2019), so they should be prioritized to test potential adaptation strategies.

\section{PRIORITY ISSUES FOR ADAPTATION}

Brazil has specific legislation and institutions to deal with its water resources and has projects and programs aligned with the Sustainable Development Goals (SDGs). However, the legislation and instrument's implementation do not consider the climate change effects. In this context, political and institutional flexibility, articulation, and multistakeholder participation in all scales (municipal, river basin, state, and federal) stand out as a central issue to direct adaptation actions to face climate change. The management of multiple water use with a planning system that considers and serves all actors and users of a watershed is still deficient. So far, river basin management has proved to be incipient in dealing with upstream-downstream conflicts regarding access and water quality equity. There is also regional heterogeneity in institutional capacity. There is no mobility and access to services in parts of the Amazon biome and sometimes even food for the riverside population when significant floods and droughts occur. The elaboration and implementation of state and river basin plans are still an institutional challenge. In the Caatinga, Pantanal, Cerrado, and Atlantic Forest biomes, most of the territory already has water resources plans, programs, and basin committees. However, the existing institutional structure was insufficient to avoid the recent water crises' impacts and conflicts. The management instruments still need to be implemented, as is the case with basin plans in the Caatinga basins. The worst fire scenario was registered since its monitoring in mid-2020 at the Pantanal. The absence of the traditional flood at the beginning of the year and the lack of dialogue between monitoring and institutional action contributed to the Pantanal's devastation scenario. The plans and programs implemented in the Atlantic Forest could not avoid the problems and conflicts in water supply in the 2014 intense drought. 
Throughout the national territory, the difficulty of articulation between existing legislation persists, such as municipal master plans, agro-ecological zoning, and legislation on land use and occupation. Also, institutions, existing public policies, and the different actors involved in their different action levels still need to connect themselves. A multistakeholder governance system is essential for the water management evolution and efficiency in order to avoid water crises and minimize the damage of extreme events and increase in sea levels (ARAUJO et al., 2019; LEMOS et al., 2020; MILHORANCE et al., 2020; MILHORANCE \& BURSZTYN, 2019).

The water quality and quantity monitoring network (surface and underground) improvement and expansion would support pollution control, especially in distant urban centers and rural areas. The institutional improvement and strengthening to assure the services continuity and standardization represents the base to expand the services in remote areas and avoid the current data generation's interruption.

The water access infrastructure needs to be expanded, especially in parts of the country with a semiarid climate and a high population concentration. Implementing water supply reservoirs to store water and prevent water shortages and collapse caused by rainfall variability is considered a relevant adaptation action.

The premise of water as an abundant natural resource acts as a pressure factor for water systemseven water scarcity existing for the current and future situations. Water losses occur mainly in the leaking of water distribution pipes, industrial and agricultural system waste, especially in the irrigation systems, such as the central pivot. Reducing water losses can be considered an adaptation priority issue since it optimizes and reduces the resources used.

Limited and sometimes almost absent, the current sanitation services access places Brazil in a vulnerable situation. It directly influences water potability and affects the various social sectors. A climatic uncertainty situation will likely amplify this vulnerable condition. Thus, provide sanitation universalization services is an urgent issue for adaptation priorities. Sanitation influences health conditions, economic development, and the environment and, once implemented, brings direct benefits with no regrets to society.

\section{ADAPTATION OPPORTUNITIES}

The primary water resources challenge to deal with climate change is to ensure the already existing management instruments' efficiency. It demands a management system designed for a dynamic, diverse, and non-stationary climate system instead of a static one.The National Adaptation Plan PNA (MMA, 2016) suggests adopting essential practices to promote management instruments' effectiveness and deal with climate changes:

- Integrate water bodies regulation goals and municipal sanitation plans

- Expand clean-up actions financing routes

- Frame water bodies regulation considering future climate scenarios

- Expand and update water quality monitoring standards

- Connect the licensing and water grant agencies for shared water bodies regulation goals

Connect, integrate and articulate stakeholders in plans and program implementation in a multiscale perspective is an action that supports adaptation policies. At the municipal scale, environmental governance systems proved to be effective and reduced deforestation in the Amazon (FERREIRA COSTA, 2020). 
The Brazilian Water Law is designed based on the stakeholder's integration at the local, state, and federal levels. Its effectiveness fails when this integration does not occur. Consequently, a necessary adaptation action in Brazil is the institutional strengthening to guarantee its instruments' effectiveness.

Surface and groundwater quality and quantity monitoring is the core to provide water bodies control. It sets updated and adjustable parameters definition. Allows the establishment of goals considering priority and agreed upon between users of the hydrographic basins. The expansion of the current system to reach a well-established monitoring system provides the basis for dynamic and flexible management. It is a step forward to establish a reference flow for framing water bodies and adjustable decision-making.

Elaboration of contingency plans for droughts and floods, with long-term planning and periodically reviewed and constant updating of investment and financing plans, strengthen institutions' decisionmaking regarding risks.

Strengthening institutional capacity also improves confidence levels and allows other adaptation instruments implementation that promotes water security. The water markets and trade are instruments of adaptation (FGV-EAESP / FGVces, 2018). In Brazil, low levels of trust and confidence for impersonal transactions can restrict water rights markets to small, close and homogeneous groups.

Investing in water use efficiency actions to reduce water losses also prevents availability and demand water conflicts. It involves a broad context that includes improvements of urban network system measurement and crop irrigation techniques, legal requirements, and water reuse support in the various sectors.

The actions involving the water losses reduction in water supply systems are strategic for the decisionmaking process. It guarantees the company's sustainability and even competitiveness besides the benefits in several segments (economic, technological, energy, socio-cultural and environmental).

The rational water use promotes activity sustainability, efficiency increase, and waste reduction (ANA, 2017). The legal requirements and management instruments allow authorization for water use and the charging for the use.

The climate change projections indicate a water availability reduction for Caatinga, Cerrado, and Atlantic Forest biomes (RIBEIRO NETO et al., 2016). Also, they are considered the highest users of irrigation systems in the country. Investment in techniques to reduce water use in irrigation prevents overexploitation and water shortage.

Irrigated crops have a condition of water use elasticity, and the sector can quickly adapt the volumes withdrawn to existing availabilities and prevent conflicts. Water availability monitoring and prognostic for irrigation and the replacement of current technologies for higher water-efficient technologies would reduce the country's irrigation system's water withdrawal. Also, keep the contingency plans and soil conservation strategies with an impact on water production can help achieve this goal.

The increased pressure on water resources in the national territory puts the theme of water reuse in evidence. Reuse is defined here as the water previously used in some human activity, one or more times. The reuse supplies the need for other beneficial uses, including the original, and can be direct or indirect, and for planned actions or not.

Reuse techniques are applied in different regions of the world, especially in places like Israel, CaliforniaUSA, Jordan, and Saudi Arabia. Israel and Jordan reuse more than $75 \%$ of the effluent flow for irrigation. California reuses $10 \%$ of the withdrawal flow, and Saudi Arabia reuses $30 \%$ of the municipal sanitary effluent after treatment. All locations mentioned have plans and targets for expanding reuse water for 2030. 
Reuse represents a relevant alternative to reach the national legislation goals. However, it still needs clear guidelines and milestones at the national and local scale. The existing reuse policy resulted in few projects implementing at the national territory, even in basins considered critical. Brazil has $2 \mathrm{~m} 3 / \mathrm{s}$ installed capacity for non-potable reuse and an expansion target of $13 \mathrm{~m} 3 / \mathrm{s}$ by 2030. Israel already has $11 \mathrm{m3}$ / s, and California has the goal to reach 50 m3 / s by 2030 (MC-IICA, 2017; NRC, 2012).

The current scenario highlights three main actions to expand the reuse in Brazil:

- Strength the leadership to define guidelines and implement the proposed reuse policy, starting with states with the current and projected most critical basins.

- Review the current legislation to improve the concept, objectives, goals, and Federal Government actions to reinforce the existing components.

- Project monitoring to review and incorporate new adjustments as needed.

The water infrastructure increment to enhance water supply and sanitation services is also considered an adaptation action. The current one is inadequate to meet all demands. The National Water and Sanitation Agency (ANA), in partnership with the Ministry of Regional Development (MDR), launched, in 2019, the National Water Security Plan (Plano Nacional de Segurança Hídrica -PNSH). It assesses the priority regions for structural interventions (Dams, Pipelines, Canals, and Integration Axes), with strategic and regional relevance to set a multi-users water supply. The plan also considers critical event risk mitigations (droughts and floods). The new sanitation framework (Federal Law No. 14,026, of July 15,2020 ) alters previous structural conditions' rules. It indicates the commitment to define universalization goals in the contracts for the public sanitation services provision. The goal is to guarantee water supply access for $99 \%$ of the population with safe drinking water and $90 \%$ of the population with sewage collection and treatment until December 31, 2033.

However, watershed plannings to supply Metropolitan Regions should be treated as a State Policy (ANA, 2019), aiming for an integrated and permanent solution with multiple water use. It must further consider additional solutions like green infrastructure, demand management, and territorial occupation organization.

Natural systems such as forests, floodplains, and soils can contribute to water quality maintenance. It serves as an efficient containment/control mechanism for flood events. Green infrastructure can increase resilience, increase water quality, promote soil conservation, reduce costs and bring multiple benefits to society. It represents ecosystem-based adaptation (EbA). However, there are still challenges in identifying, defining, and evaluating green infrastructure to achieve the precision standards required in engineering works. The professionalization and systematization of green infrastructure is a need. It helps to set the solution and achieve its multiple benefits globally: i. e., the opposite context we have today.

The integration of green and gray infrastructures presents itself as an adaptation measure. It offers the potential to meet water security challenges in an extreme future climate context, helping to mitigate the extreme events of droughts and floods and the pressure for water demands in several sectors.

The integration of gray and green infrastructures - such as reservoirs and water treatment plants and reforestation in river basins and floodplains - generates synergies like increasing the water quality and reduced water treatment costs. New York City saved around $22 \%$ of its water treatment costs after implementing water supply programs based on the integration of gray and green infrastructure (Bloomberg \& Holloway, 2018). In Brazil, the Vitória metropolitan region implemented a project to provide adequate water and sewage services based on river basin restoration and payment for environmental services. It estimates a net economic benefit of U\$ 13 to U\$ 18 million, with a return rate of $12 \%$ to $16 \%$. Also, it saves approximately $\mathrm{R} \$ 15$ million with the costs of inputs for water treatment and reduces the need for dredging in the port region over 30 years (Browder et al., 2019). 
The green infrastructure complements the grey in urban floods. It reduces the speed and amount of water that reaches the ground and relieving urban drainage systems, typically overloaded in heavy rain events.

The forest maintains and increases the soil's water storage capacity, reducing the demand for crop irrigation and fertilizers, and serves as a mechanism for erosion and diffuse pollution control.

The forest protection is the core idea for the agricultural practices program recommended by the Brazilian Agricultural Research Corporation - Embrapa in all Brazillian biomes. The projects consist of a forest-crop-livestock integration production system adapted for tropical and subtropical climates.

\section{FINAL CONSIDERATIONS}

The nexus + approach guided us in highlighting non-regret adaptation opportunities to ensure water security in Brazil under climate change threads.

The first option is strengthening institutional capacity. It is considered an institutional and technological measure with a national scoping. The water quality and quantity monitoring subsidize the demand for regulations and flexibility to face climatic scenarios uncertainty. It guides the management and planning instruments for surface and groundwater control. Its implementation is considered the pillar to achieve sustainable development at the local scale. It supports the monitoring and guidelines definition regarding local and regional particularities. Climate simulations are also included in this option since they allow defining extreme climate horizons. The governments and population can plan contingency measures based on the long term scenarios.

The second option is the promotion of water use efficiency actions. It is considered a useful measure of structural, institutional, technological, and economic character. Efficient water use has direct economic and environmental gains, reducing water losses and waste and production and consumption costs. The Caatinga, Cerrado, Atlantic Forest and, Pampa biomes are the priorities due to their growing water demands.

The third option is to increase the water infrastructure to improve the water supply. It is a measure of structural and economic character with immediate effects. It highly depends on institutions that control and regulate the resource and frequent environmental education activities. It also depends on the creation of a scarcity culture and high climatic risk to protect ecosystem services. The consumption optimization measures, institutional regulation, and maintenance of ecosystem services are interconnected. If not, it is considered an incipient action in the long run. Its scope mainly involves the Caatinga and the municipalities that do not have supply reservoir systems.

The fourth option is the integrated green (EbA) and gray infrastructure implementation. It has structural, technological, and institutional nature. It also has human development and natural and economic resources management integration characteristics. Its scope is national, with a focus on urban and rural areas. The integration of green and gray infrastructure has the potential for multiple environmental and social benefits and synergies. Integration of local communities and ecosystem services maintenance and restoration keep water security in the long term.

Population firstly and strongly perceives the water climate change effects. With the likely changes in precipitation patterns and the river flow, the most impoverished populations are the most vulnerable. Nowadays, due to geographic issues or the lack of sanitation, they are exposed to water scarcity. Thus, this study presents a pragmatic set of information, reflections, findings, suggestions, and alternatives related to climate change and its impacts on water resources. We organized here some elements and guidelines for action that support decision-making in adaptation to climate extremes and climate changes. 


\section{REFERENCES}

AGRAWAL, A., \& CARMEN LEMOS, M. (2015). Adaptive development. Nature Climate Change, 5(3), $185-187$. https://doi.org/10.1038/nclimate2501

ANA. Atlas Irrigação. Agência Nacional de Águas, 2017.

ANA. Conjuntura dos recursos hídricos no Brasil 2018: informe anual, 2018.

ANA. Conjuntura dos recursos hídricos no Brasil 2019: informe anual / Agência Nacional de Águas. Agência Nacional de Águas, 100, 2019.

ANA. ODS 6 no Brasil: visão da ANA sobre os indicadores. Brasília, Distrito Federal. Agência Nacional de Águas, 2019.

ARAGÃO, L., ANDERSON, L., FONSECA, M., ROSAN, T., VEDOVATO, L., WAGNER, F., SILVA, C., ... SAATCHI, S. 21st Century drought-related fires counteract the decline of Amazon deforestation carbon emissions. Nature Communications, 2018. 9 (1), 1-12. https://doi.org/10.1038/s41467-017-02771-y

ARAUJO, M., OMETTO, J., RODRIGUES-FILHO, S., BURSZTYN, M., LINDOSO, D., LITRE, G., GAIVIZZO, L., FERREIRA, J., REIS, R., \& ASSAD, E. The socio-ecological Nexus+ approach used by the Brazilian Research Network on Global Climate Change. Current Opinion in Environmental Sustainability, 39, 62-70, 2018. https://doi.org/10.1016/j. cosust.2019.08.005

AVILA, M. R. R., \& MATTEDI, M. A. Desastre e território: a produção da vulnerabilidade a desastres na cidade de Blumenau/SC. Urbe. Revista Brasileira de Gestão Urbana, 9(2), 187-202, 2017. https://doi.org/10.1590/21753369.009.002.ao03

BLOOMBERG, M., \& HOLLOWAY, C. M. NYC Green Infrastructure Plan: A Sustainable Strategy for Clean Waterways, 2018.

BOELENS, R., HOOGESTEGER, J., \& RODRIGUEZ DE FRANCISCO, J. C. Commoditizing Water Territories: The Clash between Andean Water Rights Cultures and Payment for Environmental Services Policies. Capitalism Nature Socialism, 25(3), 2014. 84-102. https://doi.org/10.1080/10455752.2013.876867

BOICO, V., \& WENDLAND, E. Assessment of the potentiometric drawdown in the Guarani Aquifer System in Bauru / SP by a model of analytical elements. Revista Brasileira de Recursos Hídricos, 23(2), 2018.

BPBES. Relatório Temático Água: Biodiversidade, Serviços Ecossistêmicos e Bem-Estar Humano no Brasil. Aliny P. F. Pires; Vinicius F. Farjalla; Bias M. Faria; Daniel A. Rodriguez; Eli A. T. Gomes; Eldis C. Santos; Federica N. G. A. Sodré; José Sabino; Mariana A. Espécie; Mariana R. C. Pinheiro; Mauro L. Ribeiro; Reinaldo L. Bozelli; Renata F. Panosso; Roger P. Mormul; Ronaldo Barthem; Vinicius Scofield; Viviane Dib (Org.). 1a edição, São Carlos, SP: Editora Cubo. 120 páginas, 2020. https://doi.org/10.4322/978-65-00-00068-9

BRIENEN, R. J. W., PHILLIPS, O. L., FELDPAUSCH, T. R., GLOOR, E., BAKER, T. R., LLOYD, J., ... ZAGT, R. J. Long-term decline of the Amazon carbon sink. Nature, 519(7543), 344-348, 2015. https://doi.org/10.1038/nature14283

BRITO, S., CUNHA, A., CUNNINGHAM, C., ALVALÁ, R., MARENGO, J., \& CARVALHO, M. Frequency, duration and severity of drought in the Semiarid Northeast Brazil region. International Journal of Climatology, 38(2), 517-529, 2018. https://doi.org/10.1002/joc.5225

BROWDER, G., OZMENT, S., BESCOS, I. R., \& GARTNER, T. Integrating Green and Gray - Creating Next Generation Infrastructure, 2019.

COOK, C., \& BAKKER, K. Water security: Debating an emerging paradigm. Global Environmental Change, 22(1), 94-102. 2012. https://doi.org/https://doi.org/10.1016/j.gloenvcha.2011.10.011

COUTINHO, S., BURSZTYN, M., \& RODRIGUEZ, D. NEXUS+. Sustentabilidade em Debate, 2020.

ENDO, A., TSURITA, I., BURNETT, K., \& ORENCIO, P. M. A review of the current state of research on the water, energy, and food nexus. Journal of Hydrology: Regional Studies, 11, 20-30, 2017. https://doi.org/10.1016/j.ejrh.2015.11.010 
FERREIRA COSTA, C. G. New Governance Mechanisms Contributing to the Integration of National Climate Change Adaptation and Mitigation Policies in the Brazilian Amazon. Gestión y Análisis de Políticas Públicas, 135-151, 2020. https://doi.org/10.24965/gapp.i23.10641

FGV-EAESP/FGVces. Análise dos custos e benefícios das políticas públicas [recursos eletrônicos]: o caso dos instrumentos econômicos para a gestão ambiental (Escola de Administração de Empresas de São Paulo Centro de Estudos em Sustentabilidade (ed.)), 2018.

FRANCA, R. R., \& MENDONÇA, F. A. A CHEIA HISTÓRICA DO RIO MADEIRA NO ANO DE 2014: RISCOS E IMPACTOS À SAÚDE EM PORTO VELHO (RO). Revista Brasileira de Geografia Médica e Da Saúde - Hygeia, 11(21), 62-79, 2015.

FROESE, R., \& SCHILLING, J. The Nexus of Climate Change, Land Use, and Conflicts. Current Climate Change Reports, 5(1), 24-35, 2019. https://doi.org/10.1007/s40641-019-00122-1

GREY, D., \& SADOFF, C. W. Sink or Swim?? Water security for growth and development. 9, 545-571, 2007. https://doi.org/10.2166/wp.2007.021

GRIZZETTI, B., LANZANOVA, D., LIQUETE, C., REYNAUD, A., \& CARDOSO, A. C. Assessing water ecosystem services for water resource management. Environmental Science and Policy, 61, 194-203, 2016. https://doi. org/10.1016/j.envsci.2016.04.008

HOFF, H. Understanding the Nexus. Background paper for the Bonn2011. Nexus Conference: Stockholm Environment Institute, November, 1-52, 2011.

IPCC. Climate Change and Land: an IPCC special report on climate change, desertification, land degradation, sustainable land management, food security, and greenhouse gas fluxes in terrestrial ecosystems, 2019.

JOLY, C., SCARANO, F. R., BUSTAMANTE, M., GADDA, T., METZGER, J., SEIXAS, C., OMETTO, J., PIRES, A., BOESING, A., SOUSA, F., QUINTÃO, J., GONÇALVES, L., PADGURSCHI, M., DE AQUINO, M., DE CASTRO, P., \& DOS SANTOS, I. Brazilian assessment on biodiversity and ecosystem services: Summary for policy makers. Biota Neotropica, 19(4), 2019. https://doi.org/10.1590/1676-0611-bn-2019-0865

KUNERT, N., MARIA, L., APARECIDO, T., WOLFF, S., HIGUCHI, N., CARIOCA, A., ARAUJO, D., \& TRUMBORE, S. Agricultural and Forest Meteorology A revised hydrological model for the Central Amazon: The importance of emergent canopy trees in the forest water budget. Agricultural and Forest Meteorology, 239, 47-57, 2017. https://doi.org/10.1016/j.agrformet.2017.03.002

LAPOLA, D. M., SILVA, J. M. C. D., BRAGA, D. R., CARPIGIANI, L., OGAWA, F., TORRES, R. R., BARBOSA, L. C. F., OMETTO, J. P. H. B., \& JOLY, C. A. A climate-change vulnerability and adaptation assessment for Brazil's protected areas. Conservation Biology, 34(2), 427-437, 2020. https://doi.org/10.1111/cobi.13405

LEMOS, M. C., MANUEL-NAVARRETE, D., WILLEMS, B. L., CARAVANTES, R. D., \& VARADY, R. G. Advancing metrics: models for understanding adaptive capacity and water security. Current Opinion in Environmental Sustainability, 21, 52-57, 2016. https://doi.org/10.1016/j.cosust.2016.11.004

LEMOS, M. C., PUGA, B. P., FORMIGA-JOHNSSON, R. M., \& SEIGERMAN, C. K. Building on adaptive capacity to extreme events in Brazil: water reform, participation, and climate information across four river basins. Regional Environmental Change, 20(2), 2020. https://doi.org/10.1007/s10113-020-01636-3

LIEHR, S., RÖHRIG, J., MEHRING, M., \& KLUGE, T. How the social-ecological systems concept can guide transdisciplinary research and implementation: Addressing water challenges in central northern Namibia. Sustainability (Switzerland), 9(7), 2017. https://doi.org/10.3390/su9071109

MAGRIN, G., MARENGO, J., BOULANGER, J.-P., BUCKERIDGE, M. S., CASTELLANOS, E., POVEDA, ... (Ed.), Climate Change: Impacts, Adaptation, and Vulnerability. Part B: Regional Aspects. Contribution of Working Group II to the Fifth Assessment Report of the Intergovernmental Panel on Climate Change (pp. 1499-1566). Cambridge University Press, 2014.

https://doi.org/10.1017/CB09781107415386.007 
MARENGO, J., ALVES, L., ALVALA, R., CUNHA, A., BRITO, S., \& MORAES, O. Climatic characteristics of the 20102016 drought in the semiarid northeast Brazil region. Anais da Academia Brasileira de Ciências, 90(2), 19731985, 2018. https://doi.org/10.1590/0001-3765201720170206

MARENGO, J., CUNHA, A., NOBRE, C., RIBEIRO NETO, G., MAGALHAES, A., TORRES, R., SAMPAIO, G., ALEXANDRE, F., ALVES, L., CUARTAS, L., DEUSDARÁ, K., \& ÁLVALA, R. Assessing drought in the drylands of northeast Brazil under regional warming exceeding $4^{\circ} \mathrm{C}$. Natural Hazards, 2020. https://doi.org/10.1007/s11069-020-04097-3

MARENGO, J., SOUZA, C., THONICKE, K., BURTON, C., HALLADAY, K., BETTS, R., ALVES, L., \& SOARES, W. Changes in Climate and Land Use Over the Amazon Region: Current and Future Variability and Trends. Frontiers in Earth Science, 6, 228, 2018. https://doi.org/10.3389/feart.2018.00228

MARENGO, J., TORRES, R., \& ALVES, L. Drought in Northeast Brazil-past, present, and future. Theoretical and Applied Climatology, 129(3-4), 1189-1200, 2017. https://doi.org/10.1007/s00704-016-1840-8

MC -IICA. Ministério das Cidades e Instituto Interamericano de Cooperação para a Agricultura - IICA. Avaliação de potencial de reuso. Elaboração de Proposta do Plano de Ações para Instituir uma Política de Reúso de Efluente Sanitário Tratado no Brasil. Interáguas. Programa de Desenvolvimento do Setor Água, 2017.

MILHORANCE, C., \& BURSZTYN, M. Climate adaptation and policy conflicts in the Brazilian Amazon: prospects for a Nexus + approach. Climatic Change, 2019. https://doi.org/10.1007/s10584-019-02456-z

MILHORANCE, C., SABOURIN, E., LE COQ, J., \& MENDES, P. Unpacking the policy mix of adaptation to climate change in Brazil's semiarid region: enabling instruments and coordination mechanisms. Climate Policy, 20(5), 593-608, 2020. https://doi.org/10.1080/14693062.2020.1753640

MME. Resenha Energética Brasileira - Exercício de 2018, 2019.

NOBRE, C. A., MARENGO, J. A., SELUCHI, M. E., CUARTAS, L. A., \& ALVES, L. M. Some Characteristics and Impacts of the Drought and Water Crisis in Southeastern Brazil during 2014 and 2015. Journal of Water Resource and Protection, 08(02), 252-262, 2016. https://doi.org/10.4236/jwarp.2016.82022

NRC. National Research Council. Water Reuse: Potential for Expanding the Nation's Water Supply Through Reuse of Municipal Wastewater. National Academy Press, Washington D.C., USA, 2012.

OECD. Water Security for Better Lives, 2013. https://doi.org/10.1007/978-981-10-4594-3_8

PBMC. Impactos, vulnerabilidades e adaptação às mudanças climáticas. Contribuição do Grupo de Trabalho 2 do Painel Brasileiro de Mudanças Climáticas ao Primeiro Relatório da Avaliação Nacional sobre Mudanças Climáticas, 2017.

RIBEIRO NETO A., DA PAZ A.R., MARENGO J.A. \& CHOU S.C. Hydrological Processes and Climate Change in Hydrographic Regions of Brazil. Journal of Water Resource and Protection 08, 1103-1127, 2016. https://doi. org/10.4236/ jwarp.2016.812087

SAMPAIO, G., BORMA, L., CARDOSO, M., ALVES, L., VON RANDOW, C., RODRIGUEZ, D., NOBRE, C., \& ALEXANDRE, F. Assessing the Possible Impacts of a $4{ }^{\circ} \mathrm{C}$ or Higher Warming in Amazonia BT - Climate Change Risks in Brazil (CARLOS A NOBRE, J. A. MARENGO, \& W. R. SOARES (eds.); pp. 201-218), 2019. Springer International Publishing. https://doi.org/10.1007/978-3-319-92881-4_8

SARAIVA, M. A. Avaliação da sustentabilidade do uso da água do aquífero alter do chão na zona urbana de manaus. Universidade Federal do Amazonas, 2017.

SCARANO, F. \& CEOTTO, P. Brazilian Atlantic forest: impact, vulnerability, and adaptation to climate change. Biodivers Conserv, 24:2319-2331, 2015. DOI 10.1007/s10531-015-0972-y.

SIMPSON, G. B., \& JEWITT, G. P. W. The development of the water-energy-food nexus as a framework for achieving resource security: A review. Frontiers in Environmental Science, 7(FEB), 1-9, (2019). https://doi.org/10.3389/ fenvs.2019.00008 
TOMAS, W. M., DE OliVEIRA ROQUE, F., MORATO, R. G., MEDICI, P. E., CHIARAVALLOTI, R. M., TORTATO, F. R., PENHA, J. M. F., IZZO, T. J., GARCIA, L. C., LOURIVAL, R. F. F., GIRARD, P., ALBUQUERQUE, N. R., ALMEIDA-GOMES, M., ANDRADE, M. H. D. S., ARAUJO, F. A. S., ARAUJO, A. C., ARRUDA, E. C. D., ASSUNÇÃO, V. A., BATTIROLA, L. D., ... JUNK, W. J. Sustainability Agenda for the Pantanal Wetland: Perspectives on a Collaborative Interface for Science, Policy, and Decision-Making. Tropical Conservation Science, 12, 2019. https://doi.org/10.1177/1940082919872634

UN Water. Water Security and the Global Water Agenda. In A UN-Water Analytical Brief, 2013. https://doi. org/10.1016/0022-1694(68)90080-2

VAN BEEK, E., \& ARRIENS, W. L. Water Security: Putting the Concept into Practice. In Stockholm Environment Institute, 2014. https://doi.org/10.1016/j.jag.2014.04.022

WATERAID. Water security framework, 2012. WaterAid. https://doi.org/WAT-17

WWC, W. W. C. A Pact for Water Security. In World Water Council, 2013. https://doi.org/10.1016/S03682048(97)00128-X 